IZA DP No. 5673

Youth Unemployment in Europe and the United States

David N.F. Bell

David G. Blanchflower

April 2011 


\title{
Youth Unemployment in Europe and the United States
}

\author{
David N.F. Bell \\ University of Stirling \\ and IZA \\ David G. Blanchflower \\ Dartmouth College, University of Stirling, \\ CESifo, NBER and IZA
}

\section{Discussion Paper No. 5673 \\ April 2011}

IZA

P.O. Box 7240

53072 Bonn

Germany

Phone: +49-228-3894-0

Fax: +49-228-3894-180

E-mail: iza@iza.org

\begin{abstract}
Any opinions expressed here are those of the author(s) and not those of IZA. Research published in this series may include views on policy, but the institute itself takes no institutional policy positions.

The Institute for the Study of Labor (IZA) in Bonn is a local and virtual international research center and a place of communication between science, politics and business. IZA is an independent nonprofit organization supported by Deutsche Post Foundation. The center is associated with the University of Bonn and offers a stimulating research environment through its international network, workshops and conferences, data service, project support, research visits and doctoral program. IZA engages in (i) original and internationally competitive research in all fields of labor economics, (ii) development of policy concepts, and (iii) dissemination of research results and concepts to the interested public.
\end{abstract}

IZA Discussion Papers often represent preliminary work and are circulated to encourage discussion. Citation of such a paper should account for its provisional character. A revised version may be available directly from the author. 
IZA Discussion Paper No. 5673

April 2011

\section{ABSTRACT \\ Youth Unemployment in Europe and the United States ${ }^{*}$}

This paper focuses particularly on youth unemployment, why we should be concerned about it, why it is increasing again, how the present difficulties of young people entering the labour market differ from those of the past and what useful lessons have been learned that may guide future policy. We focus on Europe and USA, but introduce evidence from other countries where appropriate. Our analysis of the UK NCDS birth cohort data provides evidence supporting the notion that early adulthood unemployment creates long lasting scars which affect labour market outcomes much later in life. Our chosen variables are weekly wages and happiness. Our results show significant effects at age 50 from early adulthood unemployment. These affects are stronger than more recent unemployment experiences.

JEL Classification: J31, J64

Keywords: $\quad$ youth unemployment, scarring effects, happiness

Corresponding author:

David G. Blanchflower

Department of Economics

6106 Rockefeller Hall

Dartmouth College

Hanover, NH 03755-3514

USA

E-mail: blanchflower@dartmouth.edu

* Thanks to Lars Calmfors, Bob Hart, Stephan Heblich, Bertil Holmlund, Chris Pissarides, and Oskar Nordström Skans for helpful comments. 
"Young people have suffered a disproportionate share of job losses during the global economic crisis. Many governments have boosted spending on programmes to help them. But with the economic recovery still fragile and fiscal pressures mounting, there are concerns that many will be left behind and could face years of unemployment."

Off to a good start? Jobs for youth, OECD, 15 ${ }^{\text {th }}$ December 2010.

Youth unemployment is one of the most pressing economic and social problems confronting those countries whose labor markets have weakened substantially since 2008, following the near-collapse of worldwide financial markets. There is an element of déjà vu around this development: youth unemployment first became a serious problem for industrialized countries during the 1980s. While labour markets were booming in the early part of this century, youth unemployment was still a concern. But the particularly rapid increase in youth unemployment during the current recession has again sharpened attention on this issue.

This paper focuses particularly on youth unemployment: why we should be concerned about it, why it is increasing again, how the present difficulties of young people entering the labour market differ from those of the past and what useful lessons have been learned that may guide future policy. We focus on Europe and USA, but introduce evidence from other countries where appropriate.

Table 1 presents evidence on the increase in quarterly youth unemployment rates over the recession. In the EU as a whole, rates have increased from $14.7 \%$ at the beginning of 2008 to over 20\% in 2010Q3. ${ }^{1}$ Youth unemployment has risen sharply in Estonia $(+20.7)$, Ireland (+18.4), Latvia (+23.2), Lithuania (+26.1) and Spain (+21.6), with percentage point increases in parentheses. Interestingly, in all these countries there have been sharp declines in house prices over the Great Recession. A direct link to the youth labour market may derive from the disproportionate number of the young who work in construction, which has suffered particularly from the effects of property price bubbles.

Some countries have been strikingly successful in keeping youth unemployment down. Strikingly, Germany has actually experienced a decrease in youth unemployment rates, down from $10.2 \%$ in 2008Q1 to $8.8 \%$ in 2010Q3. The general impact of short-term working subsidies and the particular effects on the youth labour market of the German system of dual vocational training are candidate explanations for this success.

Of particular concern is the rising number of young people disconnected from both education and the labour market. On average in the OECD, almost $11 \%$ of all young people aged 15-24 were NEET (Not in Education nor in Employment or Training) in 2008. Of these, $33 \%$ had been unemployed for less than a year, $7 \%$ were unemployed for more than a year, and $60 \%$ were inactive without studying.

\footnotetext{
${ }^{1}$ According to the OECD youth unemployment, ages 15-24 also increased in Australia (2008=8.9\%; $2009=11.6 \%)$; Canada (11.2\% and 15.3\%); Japan (7.2\% and 9.1\%); Korea (9.3\% and 9.8\%)
} 
Recent data up to the second quarter of 2010 suggest that during the past two years, the NEET proportion among the population aged 15-24 increased by almost 2 percentage points in OECD countries and in Europe. The OECD (2010) noted that by mid-2010 in the 26 OECD countries in which data are available, the proportion of youth aged 15-24 who were not in education, employment or training, stood at $12.5 \%$ of the total population aged 15-24, up from $10.8 \%$ in 2008. This represents 16.7 million young people, 10 million of whom were inactive and not studying, and 6.7 million of whom were unemployed. The OECD projects that youth unemployment rates will remain high at around 18\% in 2011 and 17\% in 2012 after a small decline in $2010 .^{2}$

To analyze the increase in youth unemployment, we examine the most recently available micro-data files to paint a picture of unemployment in general and youth unemployment in particular across countries on a comparable basis controlling for personal characteristics. These are mostly based on survey responses by individuals, but we also make use of a company level survey in Europe. Strikingly, the influences on the likelihood of an individual being unemployed are very similar across most countries and over time.

We find that youth unemployment has broadly similar features across countries, being heavily concentrated among the least educated. However, young people are optimistic about the future and particularly happy. Unemployment lowers the happiness of the young, but less so than it does for older workers. In part this may arise from the fact that a high proportion of young people in many countries continue to live with their parents, which may lessen the impact of being unemployed (Card and Lemieux, 2000, Chiuri and Del Boca 2008). Despite this, we find evidence that spells of unemployment when young tend to leave permanent scars.

A great deal of what is known about the youth labor market comes from a series of research volumes published by the National Bureau of Economic Research. These were based primarily, but not exclusively on research done in the United States (Freeman and Wise, 1982; Blanchflower and Freeman, 2000). The OECD has updated the evidence on youth through its recent analysis of youth labour markets in sixteen countries. ${ }^{3}$

\section{The effects of the Great Recession on youth labour markets}

Table 2 reports how some of the mature economies have been impacted by the recession. It shows how GDP by country changed from the first quarter of 2008 to the third quarter of 2009 - the period generally associated with the "recession" phase. It also shows the extent of growth during the "recovery" phase - which thus far stretches from the fourth quarter of 2009 to the second quarter of 2010.

\footnotetext{
${ }^{2}$ OECD youth unemployment rates were $2002=13.4 \%$ : 2003=13.8\%; 2004=13.7\%; 2005=13.4\%; 2006=12.5\%; 2007=12.0\%; 2008=12.7\%; 2009=16.4\%. Source: OECD. http://www.oecd-ilibrary.org/employment/youth-unemployment-rate_20752342-table2

3 Studies are available in Australia, Belgium, Canada, Denmark, France, Greece, Japan, Korea, the Netherlands, New Zealand, Norway, Poland, the Slovak Republic, Spain, the UK and the USA at http://www.oecd.org/document/59/0,3343,en_2649_34747 38019131_1_1_1_1,00.html
} 
Some countries, such as the Baltic States and Ireland, suffered double digit falls in output. The output of the European Union as a whole fell by $4.6 \%$ during this recessionary phase - much sharper fall than the 3.8\% drop in output experienced in the United States. The recovery has been much less strong in some parts of Europe than it has been in the US, in terms of the proportion of the drop in GDP that has since been recovered.- by 2010Q2, output in the EU was still 3\% below its level at the start of 2008. In Western Europe, Germany, Denmark and Sweden have experienced rapid growth: but growth in Spain, Italy, Ireland and France has been much weaker.

Table 2 also includes information on changes in employment from the start of the recession (2008Q1) to the most recently available observation (2010Q2). Employment in the European Union fell by $1.3 \%$ over this period. Again, in some countries the change has been much more dramatic with Ireland, Latvia and Lithuania and Estonia experiencing double-digit reductions in employment. In contrast, some countries have experienced small increases in employment. These include Germany, Austria, Sweden and Norway.

While all of the mature economies were affected by the financial crisis, the responses of both their product and labour markets have been very diverse. And indeed, while there is a general correlation between changes in output and changes in employment across countries, it is by no means uniform. Thus, for example the US and Spain both experienced falls in output of around 4\% during the recession. Employment in the US fell by almost $8 \%$ while in Spain it fell by $9.4 \%$. In contrast, output in the UK dropped by $6.2 \%$ but employment fell by only $1.7 \%$. And there is an even greater contrast with Sweden, where output fell by 6.9\% between 2008Q1 and 2009Q3, but employment actually grew between 2008 and 2010 .

For the EU as a whole, the overall fall of $1.3 \%$ in employment during the recession comprises a $2.5 \%$ reduction in full-time employment and a $4.2 \%$ increase in part-time employment. In the US, the response is even starker, with full-time employment falling by $7.9 \%$ while part-time working increased by $10.1 \%$. Reductions in hours of work as a response to the recession in the UK, has been documented in Bell and Blanchflower (2010, 2011). They find that many workers would prefer to work longer hours, but that employers are unwilling to purchase these hours. However, reduced hours may still be a rational strategy for both employers and employees who do not wish to dissipate the specific human capital that they may have jointly accumulated. They also find that not only is unemployment prevalent among the young, so is underemployment.

The young do not generally possess much specific human capital. And as a result, it is perhaps not surprising that they have been particularly affected by this recession. There is evidence that the youth labour market is especially volatile. When aggregate unemployment increases, youth unemployment tends to rise as firms cease hiring. This hurts new entrants. If firms decide to reduce their workforce and use last-in first-out (LIFO) rules to determine who is made redundant, the young are often the first to be fired. The recession has made it particularly difficult for young people to make a successful transition from school to work. 
The first panel of Table 3 presents data on the relationship between youth and adult unemployment rates. The second panel shows unemployment rates for all ages. First, it is clear that youth unemployment rates are always higher than adult rates in every country. Second the ratio of youth to adult rates tended to rise in 2008 as the recession started to bite and as national unemployment rates started to rise. Subsequently in most countries youth unemployment rates have stabilized or fallen back slightly, perhaps as a result of specific government policies to help younger workers.

One response to rising youth unemployment has been to return, or prolong, full-time education (Rice, 1999). This implies that the 16-24 cohort are now better qualified than they were during the last recession. In the UK, 5.8 per cent of $16-24$ year olds were graduates in 1993, while in 2008 that share had risen to 13.2 per cent. The improvement in qualifications is more concentrated among females than males. By 2008, the proportion of females aged 18-24 with no qualifications had fallen to 4.6 per cent, but for males was still over 7 per cent. In the UK, applications to attend university are up sharply since 2008. ${ }^{4}$ Employment subsidies have also helped young people to find jobs as they lower their relative price.

Table 4 presents employment rates for 15-24 year olds at the start of the recession in 2008Q1 and the latest data at the time of writing for 2010Q2. Employment rates for youngsters in most countries have fallen, but there are four exceptions where they have increased - Austria, Finland, Romania and Sweden. Unemployment rates for the least educated in the International Standard Classification of Education (ISCED) categories 02 jumped sharply in many countries with the biggest increases in Ireland, Latvia, and especially Spain that have high youth rates (Table 1$){ }^{5}$ Interestingly youth employment rates also increased for the most educated (ISCED 5-6) in a number of countries, notably Finland, France and Sweden The unemployment problem of this age group is not solely the preserve of the uneducated.

In Table 5, we analyze how the probability of being unemployed has varied through time and by age group in the USA and Europe. We use two micro-datasets: the Mannheim Trend file (supplemented with Eurobarometer data in 2010) and the Current Population Surveys in the United States. The European data cover Belgium, Denmark, France, Germany, Ireland, Italy, Luxembourg, the Netherlands, and the UK. We apply the same set of controls - gender, schooling and country (state in the USA) to each dataset. We report the coefficients on the various age dummies from a number of individual regressions. The coefficients in Table 5 indicate that the incidence of unemployment is increasingly falling on the young, and, as in the 1980s, recession is greater in Europe currently than in the United States. In 2010, it is 17 percentage points higher among 1524 year olds in Europe in comparison to 45-54 year olds compared with just 7.6

\footnotetext{
${ }^{4}$ As of Monday $22^{\text {nd }}$ November 2010 total applications were up $11.7 \%$ compared with the same date in 2009.

${ }^{5}$ http://www.unesco.org/education/information/nfsunesco/doc/isced_1997.htm
} 
percentage points in the USA. Although this is a continuation of previous experience, it is worth noting that this recession is unusual in that the overall unemployment rate in the US has risen above the European rate for the first time in some decades. But youth unemployment problems continue to be more severe in Europe than in the USA.

Table 6 provides a supply-side explanation of the rise in youth unemployment. The youth cohort is large at a time when the labor market is in the doldrums. The table reports the relative size of the number of 5, 19, 15 and 25-year olds compared to the number of 20-year olds which is set to 100 . The decline in the youth cohort is especially marked in the Baltic countries. Progressively shrinking cohorts will have dramatic effects on the number of entrants to the labour market over the next fifteen years or so. The decline is relatively small in the US compared with other countries, in part because of its relatively high rate of immigration. Immigrants tend to be young. By 2020 the number of twenty year olds in the Euro area will have dropped by twelve percent.

The recession has reversed recent reductions in youth unemployment in the developed world. Like other groups on the margins of the labour market, the young tend to experience particularly high rates of unemployment during recessions. The current experience fits this pattern. However, the youth cohort is diminishing in size in most countries, suggesting that, in the future, an excess supply of younger workers is less likely to occur.

Table 7 uses the 2009 Eurobarometer studies \#71.2 from May-June 2009 and \#72.1 from August-September 2009 to analyze the individual characteristics associated with having lost a job during the recession, being able to keep a job, and self-assessed ability to find $a$ job. Column 1 covers the whole sample, while columns 2 and 3 are restricted to those in employment.

Males are more likely to have lost a job but they also have a greater confidence than females of being able to find a new job. Those aged 45 to 54 are significantly less likely to have lost their job than other age groups except those aged 65+. Those aged 15-24 are most likely to have lost their jobs. They are confident in their ability to find a job, perhaps because they have greater flexibility both spatially and occupationally.

Immigrants are significantly more likely to have lost their job and are less likely to believe that they can hold on to their jobs. Those with health problems have a similar set of beliefs. Among the countries, the results for Spain are particularly negative: respondents from Spain and Ireland are more likely to have lost a job, feel less secure in their ability to retain their job and also have little confidence in being able to find a job.

Column 4 makes use of data from Eurobarometer \#72.1 from August and September 2009 to estimate an ordered logit where respondents are asked how optimistic they are about the future. Youngsters are especially optimistic, and based on the youth*unemployment interaction term, the young unemployed are more optimistic than the adult unemployed, but are still less so than students or the employed. The question is whether they are right to be optimistic given that they came of age in a recession? 
In Table 8 we make use of a very recent Eurobarometer, conducted in May 2010 which contains information on attitudes to jobs. We test to see whether the young unemployed are different from the adult unemployed, by including an age $<25 *$ unemployed interaction term, which in all cases is statistically insignificant and hence they are not.

In column 1 the theme of youngsters being especially optimistic is developed further. Here the respondents are asked for their expectations for employment in their country and whether they think it will be worse, the same or better over the next year. Once again the young are more optimistic than all older age categories. Men, the Swedes and the more educated are optimistic and the unemployed and the Greeks more pessimistic.

Column 2 examines whether respondents feel that, after the financial crisis is over, the deficit should be increased to create jobs. The young are supportive, as, unsurprisingly are the unemployed themselves, along with the Irish. The most educated are opposed.

Respondents are asked to report the two most important issues they believe their country is facing from a list of ten. By far and away the most important of these is unemployment, which was stated by over half of respondents followed by $43 \%$ who mentioned 'the economic situation in our country'. ${ }^{6}$ Column 3 has the dependent variable set to one if the respondent reported that unemployment was one of their two main issues and zero otherwise. The coefficients are estimates of the relevant probabilities. The young are more likely than other age groups to say unemployment is the main problem as, unsurprisingly, are the unemployed. The main countries where unemployment is high such as Ireland and Spain along with residents of a number of east European countries, including Latvia and Lithuania say this is a concern.

Finally in column 4 we report a life satisfaction equation. Happiness measures are of interest in themselves but also more broadly it appears that such scores are correlated with positive health outcomes (Blanchflower, 2009). Happiness, for example, is associated with improved heart rate and blood-pressure measures of response to stress and lower risk of coronary heart disease. Happy people even heal faster (Ebrecht et al, 2004). Consistent with the findings in the happiness literature, most people report themselves being happy. We include a set of controls that are relatively standard in the literature including labour force status, gender, region, schooling and marital status, plus controls for smoking and exercise. It is well known in the literature that the unemployed are unhappy and that is true here; we also observe that happiness is U-shaped in age with the young happiest. Happiness is high in the Nordic countries, notably in Denmark, Iceland and Sweden.

\footnotetext{
${ }^{6}$ The full set of responses with proportions mentioning the issue in parentheses.- unemployment (51\%); economic situation (43\%); rising prices/inflation (19\%); crime (18\%); health are system (16\%); pensions $10 \%)$; taxation (8\%); immigration (7\%); educational system (6\%); terrorism (4\%); housing (3\%); the environment (3\%); energy (3\%) and defence/foreign affairs (1\%).
} 


\section{Identifying the effects of past unemployment}

Attempts to identify the scarring effects of unemployment have a long history. Heckman and Borjas (1980), Ellwood (1982) and Corcoran (1984) made early contributions, with the former two papers exploring the econometric issues associated with identifying scarring, which is a form of state dependence. There are two main issues. First, individuals may differ in those fixed characteristics that influence their likelihood of experiencing unemployment. In contrast, state dependence implies changes in actual or perceived worker characteristics due to previous unemployment history. Thus correlations between current and past unemployment may incorrectly be viewed as causal rather than being the result of individual heterogeneity. Second, omitted exogenous variables that are serially correlated may induce spurious state dependence effects.

Heckman and Borjas (1980) argue that there are three main forms of state dependence: They base their argument on a discrete-state continuous-time Markov process with an "employment" process and an "unemployment" process which respectively determine the probability of transition between these states. These probabilities are time invariant. Then it follows that the distribution of time in either state follows an exponential distribution which is independent of the time in the current state (Cox and Millar 1965). Thus the length of time in the current spell of unemployment does not affect the rate of transition out of this state and hence there is no state dependence. By changing the structure of this model, they formalize their three models of state dependence.

In the first type, the event of unemployment alters the probability of being in the unemployed state. This is known as occurrence dependence and means that the chance of being unemployed at present increases with the number of previous unemployment spells. The second type, duration dependence, posits that the probability of staying unemployed depends on the length of the current unemployment spell and therefore requires relaxation of the time-invariance aspect of the Markov process. The third type is a natural extension of the second, and is known as lagged duration dependence and posits that the probability of unemployment depends on the lengths of previous spells of unemployment and not just the current spell. Heckman and Borjas further note that the probabilities of unemployment may vary both with time and, crucially for our application, age.

The issue of finding a consistent estimate for the lagged duration dependence form of state dependence is analogous to the problem of finding a consistent estimator for a model with a lagged dependent variable and serially correlated errors. Estimators for the other forms are more complex. Consistency for the lagged duration dependence case can be achieved through the use of an appropriate instrument. Gregg (2001) investigated lagged duration dependence using the UK National Child Development Survey (NCDS). Seeking to explain whether individuals were unemployed at the ages of 28 and 33, he used local area unemployment at age 16 as an instrument for unemployment experience up to the age of 23. His argument for this instrument was that the local labour market in which individuals find themselves at age 16 is largely exogenous. Variations in conditions in these markets will explain some of the variation in early labour market experience strengthening its case as a valid instrument. However, he acknowledges that 
the local labour market will not be independent of parental characteristics, which may also influence children's subsequent labour market experience. This weakens the validity of the instrument. In general, it is difficult to find a truly exogenous instrument within the labour market. Interdependence is characteristic of the labour market, particularly if one takes account of serial correlation. Nevertheless, Gregg argues that his instrument "does at least take the unobserved heterogeneity back a generation" (P 637) His results suggest that the number of months of unemployment between the ages of 28 and 33 increases by two months for every three months spent unemployed before the age of 23 .

Gregg and Tominey (2005) also use data from the NCDS and apply the same identification strategy as Gregg (2001) and find that there is a significant wage penalty of youth unemployment on males even after controlling for education, region and a wealth of family and personal characteristics. Their results suggest a scar from youth unemployment of $13-21 \%$ at age 41 although this penalty was lower at $9-11 \%$ if individuals avoid repeat exposure.

Taking a different approach, Beaudry and DiNardo (1991) use a cohort-based argument to identify state dependence. They argue that the distribution of heterogeneity is constant across cohorts, but that cohorts have differential experience of unemployment because they enter the labour market at different stages of the economic cycle. They argue that current wages may be affected by past labour market experience since, in a world of long-term contracts, workers' current wage will reflect the reservation wage of workers at the time they entered the labour market which in turn depends on unemployment rates at that time.

Similar evidence that even youngsters who choose to go to college or university are hurt if they enter the labour market during a recession is provided by Kahn (2010). She has shown that the labour market consequences of graduating from college in a bad economy have large, negative and persistent effects on wages. Lifetime earnings are substantially lower than they would have been if the graduate had entered the labour market in good times. Furthermore, cohorts who graduate in worse national economies tend to end up in lower-level occupations.

Research by Giuliano and Spilimbergo (2009) suggests that the period of early adulthood (between 18 and 25) seems to be the age range during which people are more sensitive to macroeconomic conditions. They find that being exposed to a recession before age 17 or after age 25 has no impact on beliefs about life chances. However, youngsters growing up during recessions tend to believe that success in life depends more on luck than on effort; they support more government redistribution, but have less confidence in public institutions. Recessions seem to adversely effect youngsters’ beliefs.

Nordström Skans (2004) uses sibling fixed-effects to identify the effect of previous unemployment on current labour market outcomes. In a search theory of the labour market, individual outcomes may be affected by entirely random events. State dependence is indicated if the effects of these events persist. The use of siblings is aimed at controlling for other influences on labour market outcomes. Differences between 
siblings that are correlated with early unemployment and subsequent labour market outcomes are controlled for using observed individual characteristics.

Skans compares the siblings model with OLS estimates where unobserved individual components are proxied by observable family characteristics instead of the sibling fixed effect. This model requires strong identification assumptions to infer causation. All differences between individuals that are correlated with both initial unemployment and later labour market performance must be captured either by observed individual or family controls.

The results from the siblings fixed-effects model show a significant negative effect on earnings for up to five years following initial unemployment. These effects decline over time and are consistent with a theoretical model where employers' recruitment decisions are more influenced by recent unemployment spells. The individual-based model gives somewhat larger state dependence effects, which potentially, but not necessarily, suggests that OLS estimates are upward biased.

In previous work (Bell and Blanchflower 2010) we examine the relationship between current unemployment and previous unemployment spells. We focus firstly on the negative effects of lagged unemployment durations on subsequent wages, building on the literature that not only includes Gregg and Tominey, but also Mroz and Savage (2006), Nickell et al. (2002) and Stewart (2000). The underlying argument is that prolonged spells of unemployment reduce human capital and act as a negative signal to employers, both of which are likely to adversely affect the future evolution of wages. The novelty of our approach is the use of the most recent data from a birth cohort study, the NCDS whose members were aged 50 at the time of the most recent sweep.

\section{Data and Empirical Analysis}

Consider an equation of the form:

$$
y_{i t}=\beta x_{i t}+\gamma z_{i t}+f\left(U_{i 0}, . ., U_{i \tau}\right)+\lambda_{i}+u_{i t}
$$

where $y_{i t}$ is some labour market outcome for individual $i$ at time $t, x_{i t}$ is a vector of personal characteristics, $z_{i t}$ is a set of labour market characteristics, $U_{0} \ldots U_{\tau}$ are characteristics of previous unemployment spells observed in $\tau$ previous time intervals. $\lambda_{i}$ is a measure of heterogeneity for each individual and $u_{i t}$ is the disturbance. This equation is sufficiently general to capture occurrence dependence, duration dependence and lagged duration dependence. From these possibilities, we focus on the lagged duration dependence due to the relative simplicity of the estimator. Thus our estimation equation is equation (2), which is a linear version of (1), where the length of unemployment spells, $L^{U_{t}}$, is used to capture state dependence.

$$
y_{i t}=\beta x_{i t}+\gamma Z_{i t}+\mu_{0} L_{i}^{U_{0}}+. .+\mu_{\tau} L_{i}^{U_{\tau}}+\lambda_{i}+u_{i t}
$$


Our data comprises a cohort study where data have been collected at irregular intervals. Past unemployment spells will have been observed when members of the sample are at the same age. Hence the coefficients are both time and age specific. If the effects of unemployment on outcomes decline through time, one would expect $\mu_{0}>>\mu_{\tau}$. On the other hand, if early spells of unemployment have scarring effects, this expectation would be reversed i.e. $\mu_{0}<<\mu_{\tau}$. Further, if lagged unemployment is driven by fixed individual heterogeneity, then one would not expect to see large changes in the $\mu$ coefficients if local labour market conditions are controlled for.

If unobserved heterogeneity affects individuals' lifetime propensity to become unemployed, then one might expect positive correlation between the $\lambda_{i}$ and $U_{j}$ which would cause an upward bias in the coefficients on the $U_{j}$. One way to reduce this effect is to increase the number of individual controls. Another is to instrument unemployment spells. But it is also worth noting that the effects of past unemployment are likely to vary with the cycle.

We can now add to the literature on scarring by exploring some new evidence using a specification similar to (2). Following Gregg and Tominey, we use the 1958 birth cohort, the National Child Development Study (NCDS). The NCDS has followed a cohort of people who were born in one week - the $3^{\text {rd }}$ to the $9^{\text {th }}$ March 1958. There have been seven attempts to trace all members of this birth cohort to monitor their physical, educational and social development. The first three sweeps were carried out by the National Children's Bureau, in 1965, when respondents were aged 7, in 1969 (NCDS1), aged 11 (NCDS2), in 1974, aged 16 (NCDS3). The fourth sweep, NCDS4, was conducted in 1981, when respondents were aged 23. The fifth sweep was carried out in 1991, when respondents were aged 33 (NCDS5). For the sixth wave, conducted in 1999-2000, when respondents were aged 41-42 (NCDS6), fieldwork was combined with the 1999-2000 wave of the 1970 Birth Cohort Study (BCS70). The seventh sweep of NCDS was conducted in 2004-2005, when respondents were aged 46-47 years (NCDS7). The eighth and most recent sweep was conducted in 2008-09 when the respondents were aged 50.

In 1981, at age 23, there were 12,537 responses to the question of whether the respondent had ever been unemployed since the age of 16 . Unemployment rates in the UK had risen from $5.4 \%$ in 1979 to $6.8 \%$ in 1980 and $9.6 \%$ in 1981, when the UK had moved into recession. Unemployment would eventually peak at $11.4 \%$ in the spring of 1984 . In the sample, $44 \%$ reported that at some time in their working lives they had been unemployed. The question is whether unemployment when young impacts outcomes later in life and whether the effect of an unemployment spell when young is greater than when older. It turns out it is.

Using the most recent data from the 2008-09 sweep, we estimate a wage equation. Our sample is therefore limited to 6,811 employees. To capture individual and labour market characteristics, we include controls for full-time/part-time status, permanent/temporary job, region (10), school dummies (8), industry dummies (59) and workplace size (4). To test for scarring, we include the number of months unemployd before age 23 as a regressor and also whether the individual was unemployed at age 46 - effectively lagged 
unemployment. This means that we exclude from our sample nearly a thousand employees of individuals who report their wages but who either did not respond to the fourth sweep of the survey (NCDS4) or did not report the number of months unemployed.

Table 9 illustrates the difficulties of distinguishing scarring effects from individual heterogeneity. The information on IQ and math scores at age 11, and reading score at 16, suggest that these would be reasonably good predictors of months unemployed before age 23. Yet, whether the cause is scarring or heterogeneity, adverse outcomes occur, and may indicate the need for policy intervention due to lost output as well as other social and economic costs.

Our regression results are reported in Table 10. The dependent variable is the log of weekly wages at age 50. We have around 6000 observations for our simplest regression. The sample size declines as we introduce additional controls. We focus on the coefficients on early unemployment and unemployment in 2004, which is effectively, lagged unemployment, since 2004 was the time of the previous observation. As additional controls are added the size of the coefficients on the unemployment variable decline as one would expect in the presence of heterogeneity.

Following our earlier argument regarding the difficulty of finding appropriate instruments within the labour market, we use OLS, noting that in the Gregg and Tominey study, which uses the same dataset estimated over an earlier period, the IV results "are not largely different from the OLS estimates” (P 505).

The addition of controls reduces the coefficient on months unemployed aged less than 23 from -0.01382 to -.0092. Nevertheless the effect on current wages of cumulative unemployment experience when aged less than 23 is highly significant. The same cannot be said for unemployment in 2004, which is not significant even at the $10 \%$ level. Males are consistently and significantly more likely to be unemployed than females.

Our results update Gregg and Tominey (2005) using the same data. But our focus is on outcomes in the most recent sweep of the NCDS data at age 50. We also find evidence of scarring. Our evidence supports the general notion that unemployment experience in early adulthood can have a continuing negative effect on labour market outcomes even up to 3 decades later. Conditional on early labour market experience, later spells of unemployment do not negatively impact wages.

In Table 11 we examine a different outcome, again in the context of equation 1 , selfreported happiness at age 50. The sample is larger because we now include all individuals and do not restrict the samples to employees as in Table 9. The exact question asked is: on balance I look back on life with a sense of happiness ( $n=9845)$. Never $=1 \%$; not often $=7 \%$; sometimes $=34 \%$ and often $58 \%$.

Consistent with the findings in the happiness literature, most people report themselves being happy. We include a set of controls that are relatively standard in the literature 
including labour force status, gender, region, schooling and marital status, plus controls for smoking and exercise. In column 1 we include months unemployed up to age 23 in an OLS regression and this enters significantly negatively. In column 3, we also include lagged unemployment variables, from NCDS7 and NCDS6 at ages 42 and 47. Interestingly, with this variant of equation 1 , both are insignificant and the significance of the months unemployed early in life variable remains. The two more recent lagged unemployment variables are insignificant in columns 3 and 4 . So spells of unemployment while young lower happiness at age fifty, even though unemployment in the mid forties does not. And the extent of the decline in happiness increases with the number of months unemployed at this early age.

Thus we have presented stark findings, consistent with much earlier evidence that youth unemployment lowers wages and happiness over thirty-five years later. And the more months of unemployment when young, the bigger the effects. Our empirical strategy could potentially provide biased estimates. The extent to which it does so depends on the extent to which the experience of unemployment while young is simply driven by fixed effects: Some people may simply have a propensity for unemployment and the fact that there is something fundamentally different about them, rather than a result of their early labour market experiences, is why they are unemployed in later life.

We cannot fully address this issue with the data to hand. But given that youth unemployment is correlated with a number of negative outcomes, our view is that it would be dangerous to conclude that youth unemployment is simply driven by genetics. Even if the scarring we have observed was driven by the unobserved fixed effects, it is unclear why this would matter for policy. Policy should focus on reducing the harmful effects of youth unemployment whether individuals were scarred by earlier spells of unemployment or by some permanent disposition to being unemployed. It is quite clear that the most harmful effects appear to be on the least skilled and least educated. If there had been earlier interventions to help such individuals, they wouldn't be in a similar situation in their middle age. The consequences of inaction may well be large.

\section{Conclusions}

In this paper we have documented the increase in youth unemployment since the start of the Great Recession. While youth unemployment rates have increased in almost all countries, there has been wide divergence in the size of this increase. There is evidence that the least educated have been hit hardest. Particularly large increases have occurred in countries that have suffered house price declines crises such as Spain, Latvia, Lithuania and Ireland. In contrast, youth unemployment has remained relatively low in Austria, Denmark, Germany and the Netherlands

The concern is that such spells of unemployment while young have long lasting effects, which would be bad for the individuals and for the countries themselves, potentially raising the natural rate of unemployment in the long run. Our micro-econometric analysis confirms that broadly the same specification provides a consistent explanation of higher rates of youth unemployment in Europe, the USA and the UK. We also find that these specifications are also consistent through time in the UK and USA, though it appears that 
the relative disadvantage of youth in the labour market has increased during the Great Recession.

Our analysis of the UK NCDS data supports the notion that early adulthood unemployment creates long lasting scars which affect labour market outcomes much later in life. We focus on are weekly wages and happiness. Our results showed significant effects at age 50 from early adulthood unemployment that were much more significant than recent unemployment experience.

Given these negative effects of early unemployment experience, the immediate policy response might therefore be to increase the demand for labour generally, or to seek to change the balance of demand in favor of younger workers. The most readily available lever for either of these approaches is fiscal policy. But this should not be taken as suggesting that efforts to improve the education, skills and employability of the young should not also be a focus of policy intervention. This age group was not responsible for the recession. It should not be expected to pay for it through potentially long-run adverse labour market outcomes. 


\section{$\underline{\text { References }}$}

Beaudry P. and J. DiNardo (1991), The effect of implicit contracts on the movement of wages over the business cycle: evidence from micro data, Journal of Political Economy, vol 99, no 4, pp 655-688

Bell, D.N.F and D.G. Blanchflower (2007), The Scots may be brave but they are neither healthy nor happy, Scottish Journal of Political Economy, May, 54(2), pp. 166-194.

Bell, D.N.F and D.G. Blanchflower (2010), UK unemployment in the Great Recession, National Institute Economic Review, November, 214, pp. R3-R25.

Bell, D.N.F and D.G. Blanchflower (2011), Underemployment in the Great Recession, National Institute Economic Review, January.

Blanchflower D.G. (2009), International evidence on well-being, in National Time Accounting and Subjective Well-being edited by Alan B. Krueger, NBER and University of Chicago Press.

Blanchflower, D.G. and A.J. Oswald (2004), Well-being over time in Britain and the USA, Journal of Public Economics, 88(7-8), July, pp. 1359-1386.

Blanchflower, D.G. and A.J. Oswald (2008), Is well-being U-shaped over the life cycle?, Social Science \& Medicine, 66(6), pp. 1733-1749.

Blanchflower, D.G. and R.B. Freeman (editors), Youth Employment and Joblessness in Advanced Countries, University of Chicago Press and NBER, 2000.

Card D. and T. Lemieux (2000) Adapting to circumstance: the evolution of work, school and living arrangements among North American youth, in Blanchflower D. and R. Freeman (eds.) Youth Employment and Joblessness in Advanced Countries, University of Chicago Press and NBER.

Chiuri, M.C. and D. Del Boca (2008), Household membership decisions of adult children, IZA Discussion Paper No. 3546, June.

Corcoran, M. (1984), The employment and wage consequences of teenage women's nonemployment, in Freeman, R. B. and D. A. Wise, (editors), The Youth Labor Market Problem: Its Nature, Causes, and Consequences, University of Chicago Press and NBER.

Cox, D. R. and Miller, H. D. (1965), The Theory of Stochastic Processes. London: Chapman and Hall.

Ebrecht, M., Hextall, J., Kirtley, L.G., Taylor, A., Dyson, M., \& Weinman, J. (2004). Perceived stress and cortisol levels predict the speed of wound healing in healthy male adults, Psychoneuroendocrinology, 29, 798-809. 
Ellwood, D. (1984), Teenage unemployment: permanent scars or temporary blemishes?, NBER Chapters, in Freeman, R. B. and D. A. Wise, (editors), The Youth Labor Market Problem: Its Nature, Causes, and Consequences, University of Chicago Press and NBER.

Freeman, R.B. and H. J. Holzer (1986), The Black Youth Employment Crisis, University of Chicago Press and NBER.

Giuliano, P. and A. Spilimbergo (2009), Growing up in a recession: beliefs and the macroeconomy, NBER Working Paper No. 15321, September.

Gregg, P.A. (2001), The impact of youth unemployment on adult unemployment in NCDS, Economic Journal, 111(475), pp. F623-F653.

Gregg, P.A. and Tominey, E. (2005), The wage scar from male youth unemployment, Labour Economics, 12, pp. 487-509.

Heckman, J. and Borjas, G. (1980), Does unemployment cause future unemployment? definitions, questions and answers from a continuous time model of heterogeneity and state dependence, Economica, 47(187), pp. 247-83, August.

Kahn, L.B. (2010), The long-term labor market consequences of graduating from college in a bad economy, Labour Economics, 17(2), April, pp. 303-316.

Mroz, T.A. and Savage, T.H. (2006), 'The long-term effects of youth unemployment', Journal of Human Resources, Spring, 41(2), pp. 259-293.

Nickell, S., Jones, P. and Quintini, G. (2002). A picture of job insecurity facing British men, Economic Journal vol. 112(476), pp. 1 -27.

Nordström Skans, O., (2004), Scarring effects of the first labour market experience: a sibling based analysis, Institute for Labour Market Policy Evaluation. Working paper 2004:14.

OECD, 2009, OECD Employment Outlook, 2009.

OECD (2010), Off to a good start? Jobs for youth, Paris, December.

Rice, P. (1999), The impact of local labour markets on investment in higher education: evidence from the England and Wales Youth Cohort Studies, Journal of Population Economics, 12, pp. 287-312.

Stewart , M. B. (2000). 'The inter-related dynamics of unemployment and low pay', University of Warwick, mimeo. 
Table 1. Quarterly Youth unemployment Rates, 2008-2010Q3 (\%)

$\begin{array}{lrrrr} & 2010 \mathrm{Q} 3 & 2010 \mathrm{Q} 1 & 2009 \mathrm{Q} 1 & 2008 \mathrm{Q} 1 \\ \text { European Union (27) } & 20.3 & 20.7 & 18.4 & 14.7 \\ \text { Euro area (16) } & 20.0 & 20.2 & 18.4 & 14.7 \\ \text { Austria } & 8.6 & 9.6 & 9.3 & 8.2 \\ \text { Belgium } & 23.5 & 23.8 & 21.0 & 17.3 \\ \text { Bulgaria } & 20.8 & 22.1 & 13.5 & 13.8 \\ \text { Cyprus } & 20.8 & 18.7 & 10.9 & 9.1 \\ \text { Czech Republic } & 17.7 & 19.3 & 12.8 & 10.0 \\ \text { Denmark } & 14.7 & 13.4 & 9.1 & 7.2 \\ \text { Estonia } & 28.1 & 39.6 & 24.0 & 7.4 \\ \text { Finland } & 20.7 & 22.5 & 18.8 & 15.9 \\ \text { France } & 24.2 & 23.4 & 22.9 & 17.9 \\ \text { Germany } & 8.8 & 9.9 & 10.1 & 10.2 \\ \text { Greece } & 32.1 & 29.7 & 24.4 & 22.5 \\ \text { Hungary } & 27.2 & 27.0 & 24.6 & 19.7 \\ \text { Ireland } & 28.5 & 27.1 & 20.5 & 10.1 \\ \text { Italy } & 28.2 & 27.5 & 24.3 & 20.7 \\ \text { Latvia } & 34.0 & 39.0 & 27.8 & 10.8 \\ \text { Lithuania } & 35.3 & 34.1 & 23.6 & 9.2 \\ \text { Luxembourg } & 18.4 & 17.4 & 18.6 & 15.4 \\ \text { Malta } & 12.1 & 13.9 & 14.2 & 11.5 \\ \text { Netherlands } & 8.7 & 8.9 & 6.7 & 6.2 \\ \text { Norway } & 8.3 & 8.9 & 8.6 & 6.8 \\ \text { Poland } & 22.8 & 23.3 & 18.1 & 17.8 \\ \text { Portugal } & 23.0 & 21.9 & 19.1 & 15.8 \\ \text { Romania } & 21.4 & 21.0 & 20.2 & 18.5 \\ \text { Slovakia } & 32.0 & 32.9 & 22.3 & 19.1 \\ \text { Slovenia } & 15.6 & 13.2 & 12.6 & 11.2 \\ \text { Spain } & 42.4 & 39.9 & 34.7 & 20.8 \\ \text { Sweden } & 24.8 & 26.3 & 22.5 & 18.9 \\ \text { Turkey } & 19.3 & 21.1 & 22.8 & 17.0 \\ \text { United Kingdom } & 18.9 & 19.7 & 17.9 & 13.8 \\ \text { United States } & 18.2 & 18.7 & 15.7 & 11.5\end{array}$

Source: Eurostat 
Table 2. Employment Change and GDP in the Great Recession (\%)

\begin{tabular}{c|cc} 
Employment change & \multicolumn{2}{|c}{ GDP (at market prices) } \\
2008Q1-2010Q2 & 2008Q1-2009Q3 & 2009Q4-2010Q2 \\
-1.3 & -4.6 & 1.6 \\
-1.6 & -4.2 & 1.5 \\
1.6 & -2.9 & 1.6 \\
-0.2 & -1.9 & 1.3 \\
-6.6 & -1.6 & -0.2 \\
-3.6 & -5.1 & -1.3 \\
2.1 & -0.4 & 0.7 \\
-1.6 & -3.3 & 1.8 \\
-2.7 & -6.6 & 2.6 \\
-14.9 & -22.3 & 4.4 \\
0.5 & -8.4 & 2.3 \\
0.3 & -3.1 & 1.5 \\
0.7 & -4.1 & 3.0 \\
-1.9 & -1.1 & -3.4 \\
-1.7 & -7.1 & 0.6 \\
-3.2 & -7.6 & -4.6 \\
-12.9 & -12.6 & -1.5 \\
-0.7 & -6.2 & 0.8 \\
-17.7 & -26.8 & 0.5 \\
-12.1 & -15.5 & 0.4 \\
10.3 & -3.9 & 0.9 \\
4.9 & -0.1 & 2.5 \\
0.5 & -3.9 & 2.1 \\
0.9 & -2.3 & 0.4 \\
3.1 & 4.2 & 3.0 \\
-3.8 & -3.0 & 1.3 \\
4.1 & -2.8 & -1.5 \\
-3.3 & -4.2 & 3.7 \\
-0.3 & -7.0 & 1.1 \\
-9.4 & -4.4 & 0.1 \\
0.8 & -6.9 & 4.0 \\
-1.7 & -6.2 & 2.0 \\
-7.9 & -3.8 & 2.5 \\
& &
\end{tabular}

Note: * January 2008-September 2010. Source: Eurostat 
Table 3. Ratio of youth to adult annual unemployment rates and national unemployment rates, 1983-2010

$$
\begin{array}{llllll}
\text { October } 2010 \quad 2008 & 2005-7 & 2000-4 & 1990-4 & 1983-4
\end{array}
$$

\section{a) Ratio of age <25 unemployment rate to age 25-74 unemployment rate}

$\begin{array}{lrrrrrr}\text { Belgium } & 3.28 & 3.05 & 2.98 & 3.01 & 2.74 & 3.02 \\ \text { Denmark } & 2.49 & 3.04 & 2.33 & 1.80 & 1.49 & 2.33 \\ \text { Germany } & 1.33 & 1.43 & 1.38 & 1.09 & 1.21 & \\ \text { Ireland } & 2.38 & 2.61 & 2.40 & 2.24 & 1.83 & 1.76 \\ \text { Spain } & 2.34 & 2.51 & 2.54 & 2.73 & 2.99 & \\ \text { France } & 3.01 & 2.94 & 2.78 & 2.58 & 2.85 & 4.00 \\ \text { Italy } & 3.79 & 3.79 & 3.98 & 3.41 & 4.57 & 7.22 \\ \text { Netherlands } & 2.36 & 2.63 & 2.16 & 2.24 & 1.45 & 1.71 \\ \text { Portugal } & 2.25 & 2.41 & 2.36 & 2.74 & 3.13 & 4.05 \\ \text { Finland } & 3.37 & 3.37 & 3.01 & 2.80 & 3.02 & \\ \text { Sweden } & 4.21 & 4.88 & 4.20 & 3.16 & 3.18 & 3.48 \\ \text { United Kingdom } & 3.24 & 3.85 & 3.85 & 3.22 & 1.94 & 2.30 \\ \text { United States } & 2.27 & 2.78 & 2.89 & 2.77 & 2.46 & 2.34 \\ \text { b) Total unemployment rates } & \mathbf{( \% )} & & & & \\ \text { Belgium } & 8.5 & 7.0 & 8.1 & 7.5 & 7.7 & 10.8 \\ \text { Denmark } & 7.3 & 3.3 & 4.2 & 4.9 & 8.2 & 8.2 \\ \text { Germany } & 6.7 & 7.3 & 9.6 & 8.5 & 7.4 & \\ \text { Ireland } & 14.1 & 6.3 & 4.5 & 4.3 & 14.7 & 14.7 \\ \text { Spain } & 20.7 & 11.3 & 8.7 & 10.8 & 15.7 & \\ \text { France } & 9.8 & 7.8 & 9.0 & 8.8 & 9.9 & 8.5 \\ \text { Italy } & 8.6 & 6.7 & 6.9 & 8.8 & 9.3 & 7.7 \\ \text { Netherlands } & 4.4 & 3.1 & 4.4 & 3.6 & 5.3 & 8.2 \\ \text { Portugal } & 11.0 & 7.7 & 7.9 & 5.3 & 5.1 & 8.6 \\ \text { Sweden } & 8.1 & 6.2 & 6.9 & 6.3 & 5.8 & 3.5 \\ \text { United Kingdom } & 7.7 & 5.6 & 5.2 & 5.0 & 9.0 & 10.9 \\ \text { United States } & 9.8 & 9.3 & 5.8 & 5.2 & 6.5 & 8.6\end{array}$

Source: Eurostat 
Table 4. Employment rates (\%) by educational status ages 15-24 (ISCED, 1997)

\begin{tabular}{|c|c|c|c|c|c|c|c|c|}
\hline & \multicolumn{2}{|c|}{ All (ISECD 0-6) } & \multicolumn{2}{|c|}{ Pre-primary } & \multicolumn{2}{|c|}{ Upper/post-secondary } & \multicolumn{2}{|c|}{ Tertiary } \\
\hline & 2010Q3 & 2008Q1 & 2010Q3 & 2008Q1 & 2010Q3 & 2008Q1 & 2010Q3 & 2008Q1 \\
\hline Austria & 55.8 & 54.6 & 42.0 & 38.9 & 69.4 & 70.8 & 58.0 & 73.9 \\
\hline Belgium & 24.3 & 27.5 & 9.9 & 11.4 & 32.5 & 36.9 & 56.1 & 67.3 \\
\hline Bulgaria & 23.1 & 24.9 & 5.2 & 5.4 & 40.4 & 46.6 & 59.6 & 65.1 \\
\hline Czech Republic & 24.4 & 27.2 & 3.4 & 4.1 & 43.0 & 48.3 & 33.4 & 44.1 \\
\hline Denmark & 57.6 & 62.9 & 50.1 & 57.3 & 70.4 & 73.7 & 65.7 & 79.1 \\
\hline Estonia & 23.5 & 35.5 & 8.4 & 16.8 & 34.2 & 55.1 & 57.2 & 75.3 \\
\hline Finland & 43.0 & 39.3 & 26.9 & 20.1 & 63.5 & 59.5 & 87.4 & 79.9 \\
\hline France & 30.8 & 31.3 & 13.9 & 16.3 & 41.7 & 42.1 & 54.1 & 51.6 \\
\hline Germany & 45.2 & 47.5 & 32.1 & 34.8 & 63.4 & 65.7 & 71.7 & 83.8 \\
\hline Greece & 20.7 & 22.8 & 12.3 & 16.5 & 26.2 & 25.0 & 47.4 & 59.3 \\
\hline Hungary & 17.9 & 19.6 & 5.3 & 6.4 & 29.1 & 30.2 & 58.4 & 72.6 \\
\hline Ireland & 30.8 & 47.0 & 9.3 & 19.6 & 43.9 & 62.0 & 62.8 & 80.5 \\
\hline Italy & 20.5 & 24.2 & 12.3 & 15.0 & 30.9 & 36.1 & 29.3 & 30.7 \\
\hline Latvia & 26.1 & 40.1 & 9.9 & 17.7 & 37.9 & 60.4 & 76.9 & 87.9 \\
\hline Lithuania & 19.8 & 26.0 & 4.8 & 6.0 & 28.0 & 38.9 & 54.1 & 78.3 \\
\hline Luxembourg & 19.4 & 21.9 & 11.0 & 14.5 & 33.9 & 30.5 & 41.1 & 54.2 \\
\hline Netherlands & 66.0 & 68.0 & 56.8 & 59.2 & 75.0 & 77.3 & 79.6 & 81.5 \\
\hline Norway & 52.3 & 56.9 & 47.9 & 49.4 & 64.1 & 70.2 & 75.1 & 81.2 \\
\hline Poland & 26.3 & 26.6 & 6.6 & 6.5 & 41.8 & 42.3 & 52.8 & 66.9 \\
\hline Portugal & 27.9 & 34.9 & 26.0 & 34.2 & 29.4 & 32.3 & 39.2 & 61.3 \\
\hline Romania & 25.8 & 23.3 & 19.6 & 14.6 & 30.4 & 31.6 & 55.6 & 64.6 \\
\hline Slovakia & 20.6 & 27.3 & 1.8 & 2.2 & 37.2 & 47.4 & 36.0 & 66.7 \\
\hline Slovenia & 32.9 & 34.4 & 17.3 & 14.9 & 44.8 & 47.3 & 53.1 & 57.2 \\
\hline Spain & 26.2 & 36.5 & 24.4 & 38.4 & 28.3 & 36.3 & 47.2 & 57.0 \\
\hline Sweden & 43.7 & 39.0 & 26.6 & 22.4 & 63.7 & 64.6 & 68.1 & 53.1 \\
\hline United Kingdom & 47.1 & 52.4 & 34.2 & 43.2 & 55.2 & 60.5 & 72.8 & 81.0 \\
\hline
\end{tabular}

Notes: ISCED 0-2=Pre-primary, primary and lower secondary education - levels 0-2. ISCED3-4 =Upper secondary and postsecondary non-tertiary education - levels 3-4 (ISCED 1997). ISCED levels 5-6 Tertiary education - levels 5-6 (ISCED 1997) 
Table 5. Estimated probability of unemployment

USA

\begin{tabular}{|c|c|c|c|}
\hline 1979 & & & 2010 \\
\hline 15-24 years.093 & 126 & .049 & .076 \\
\hline 25-34 years .034 & 057 & .013 & .024 \\
\hline 35-44 years .009 & .023 & .003 & .006 \\
\hline 55-64 years -.005 & -.010 & .003 & -.001 \\
\hline 65+ years-.005 & -.039 & .004 & -.008 \\
\hline
\end{tabular}

\section{Europe}

1975-82 1983-89 2007 $2010 \quad 2010$ (9 countries)

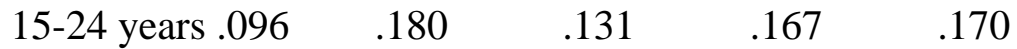

$\begin{array}{lllll}25-34 \text { years } .014 & .045 & .040 & .037 & .053\end{array}$

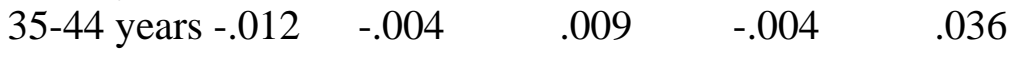

$\begin{array}{lllll}55-64 \text { years. } 029 & .037 & .041 & .005 & .020\end{array}$

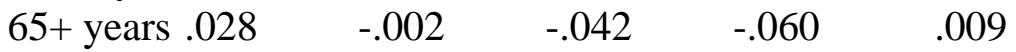

Source: Mannheim Trend file and for 2010 \#73.3 Eurobarometer and 2007

Notes: Sample for 1975-1989 is nine EU countries; Belgium, Denmark, France, Germany, Ireland, Italy, Luxembourg, the Netherlands, and the UK. Samples for 2007 are all twenty-seven EU countries. The final column is for the same 9 countries as for 1975-1989. Controls include gender, schooling and country or state. Estimated with dprobit.

Table 6. Cohort size in 2008 (age $20=100$ )

$\begin{array}{lcccc} & 5 \text { years } & 10 \text { years } & 15 \text { years } & 25 \text { years } \\ \text { Euro area } & 88 & 88 & 93 & 111 \\ \text { Denmark } & 105 & 112 & 114 & 98 \\ \text { Estonia } & 59 & 55 & 76 & 93 \\ \text { Finland } & 91 & 97 & 109 & 112 \\ \text { Germany } & 74 & 83 & 86 & 103 \\ \text { Greece } & 87 & 88 & 95 & 130 \\ \text { Ireland } & 104 & 98 & 95 & 137 \\ \text { Latvia } & 53 & 49 & 80 & 92 \\ \text { Lithuania } & 53 & 66 & 94 & 87 \\ \text { Netherlands } & 101 & 98 & 101 & 97 \\ \text { Norway } & 99 & 107 & 109 & 100 \\ \text { Spain } & 89 & 82 & 87 & 132 \\ \text { Sweden } & 86 & 82 & 111 & 95 \\ \text { UK } & 81 & 89 & 96 & 98 \\ \text { USA } & 97 & 94 & 102 & 103\end{array}$

Source: Eurostat 
Table 7. Probability of having lost, ability to keep and likelihood of finding a new job, and degree of optimism, Europe, 2009

(2)

(3)

(4)

Lost a job Ability to keep job Likely to find a job Optimistic probit ordered logit OLS ordered logit

Male $.0281(9.82) .0429(1.28)$

15-24*unemployed

$.4003(8.32) \quad .1003(4.16)$

15-24 years $\quad .0583(8.02)-.1849(2.39)$

$\begin{array}{ll}1.5383(13.93) & .2859(2.19) \\ 1.4662(8.13)\end{array}$

25-34 years $\quad .0519(9.11)-.2528(4.26)$

$1.5242(18.18) \quad .3190(7.73)$

35-44 years $\quad .0432(8.06)-.2712(4.74)$

$1.3761(17.00) \quad .1625(4.11)$

55-64 years $\quad .0422(8.10)-.2187(3.83)$

$.6696(8.32)$

$.0498(1.14)$

65+ years $\quad-.0854(17.83)-.0534(0.35)$

$-.5358(2.50) \quad .1278(2.45)$

ALS 16-19 -.0045 (1.08).2430 (4.11)

$.4980(5.77) \quad .2249(6.44)$

ALS 20+ $\quad-.0330$ (7.62) .7075 (11.37)

$1.2023(13.39) \quad .5253(13.51)$

Still studying -.0682 (14.23) $.6080(8.40)$

No FT education -.0028 (0.19) $\quad$.1959 (0.64) $\quad-.1431(0.33) \quad-.2084(1.42)$

Home worker

Unemployed

Retired/disabled

Immigrant $\quad .0756$ (10.26)-.2730 (3.42)

$-.1719(1.49)$

Health problems $\quad .0158(3.67) \quad-.2885(4.56) \quad-.6191(7.04)$

cut1/constant -3.5596

4.0107

$-1.8505$

$-.0170$

cut3 $\quad .1649$

2.2223

$\begin{array}{lccccc}\mathrm{N} & 29,484 & & 13,462 & 13,129 & \\ \text { Pseudo/Adjusted R }{ }^{2} .1124 & .0798 & & .1354 & .0590 & \end{array}$

Source: Columns 1-3 - Eurobarometer \#71.2, May - June 2000. Column 4 Eurobarometer \#72.1, August-September 2009.

Notes: Excluded categories, Age left school<16 and ages 45-54. 'Health problems' variable relates to whether the individual suffers from a chronic physical or mental health problem, which affects their daily activities. In column 1 the dependent variable is set to one if the respondent says that "as a result of the economic crisis they have lost their job", zero otherwise and includes the full sample including those studying. In column 2 the dependent variable is 'How confident would you say you are in your ability to keep your job in the coming months? Are you not at all confident; not very confident; fairly confident or very confident? The equation is estimated as an ordered logit. In column 3 the question is "if you were to be laid-off, how would you rate on a scale of 1 to 10 , the likelihood of you finding a job in the next six months? ' 1 ' means that it 'would be not at all likely' and '10' means that it 'would be very likely'. T-statistics in parentheses. In column 4 the question is 'please tell me whether you totally disagree (8.7\%), tend to disagree $(28.5 \%)$, tend to agree $(44.0 \%)$ or totally agree $(17.4 \%)$ with the following statement: You are optimistic about the future? All equations also include 29 country dummies. 
Table 8. Attitudes and expectations, 2010

(1)

Employment expectations

Ordered logit

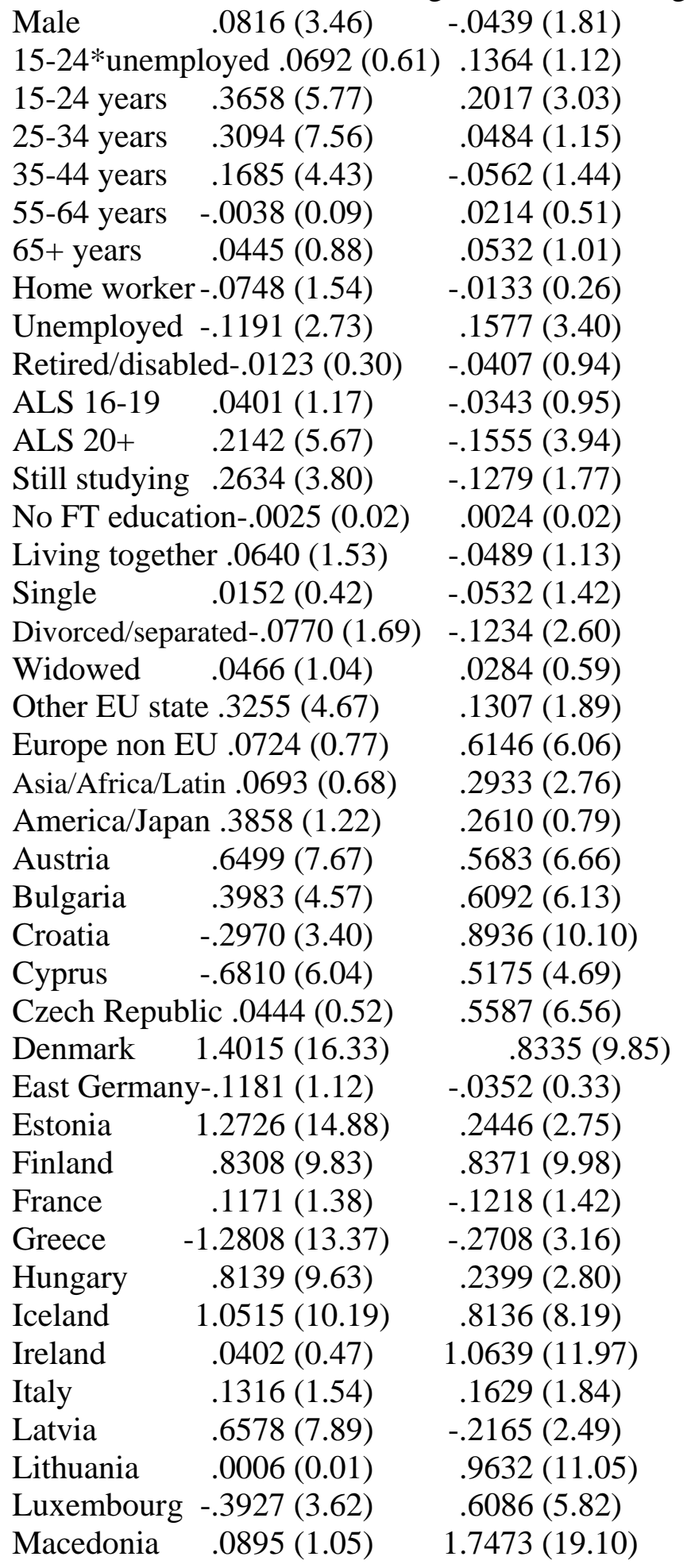

(2)

Necessary to create jobs Ordered logit
(3) Unemployment main issue Probit

$$
-.0199(3.19) \quad-.1083(4.56)
$$$$
.0139(0.45) \quad .1725(1.51)
$$$$
.0493(2.93) \quad .7983(12.24)
$$$$
.0152(1.40) \quad .3761(9.11)
$$$$
.0053(0.53) \quad .1645(4.31)
$$$$
-.0141(1.30) \quad .1288(3.12)
$$$$
-.0508(3.82) \quad .4234(8.31)
$$$$
.0288(2.27) \quad-.2595(5.35)
$$$$
.1421(12.35)-1.0957 \text { (25.10) }
$$$$
-.0054(0.50) \quad-.2314(5.54)
$$$$
-.0151(1.70) \quad .3066(9.06)
$$$$
-.0346(3.48) \quad .7817(20.55)
$$$$
-.0282(1.54) \quad .8798(12.35)
$$$$
-.0123(0.37) \quad-.5343(4.11)
$$$$
.0032(0.29) \quad-.2068(4.83)
$$$$
-.0083(0.87) \quad-.4421(12.05)
$$$$
.0060(0.50) \quad-.6695(14.67)
$$$$
-.0265(2.27) \quad-.5337(11.93)
$$$$
-.0219(1.20) \quad-.1095(1.61)
$$$$
.0434(1.76) \quad-.2596(2.83)
$$$$
.0158(0.58) \quad-.3784(3.66)
$$$$
-.0780(0.89) \quad .4890(1.41)
$$$$
-.0679(2.98) \quad-.1571(1.77)
$$$$
.0808(3.61) \quad-2.5190(28.63)
$$$$
.1716(7.78) \quad-.8078(8.85)
$$$$
-.0466(1.68) \quad-.2290(2.08)
$$$$
.0311(1.38) \quad-.8571(9.71)
$$$$
-.0557(2.44) \quad 1.6625(17.53)
$$$$
-.0087(0.31) \quad-.8928(8.24)
$$$$
.2445 \text { (11.38) -1.1404 (12.98) }
$$$$
.0833(3.74) \quad .3291(3.72)
$$$$
.1404(6.41) \quad-.4543(5.13)
$$$$
-.0111(0.49) \quad-2.3419(26.54)
$$$$
.1502(6.82) \quad-1.8973(21.70)
$$$$
.0853(3.17) \quad 1.0579 \text { ( 9.62) }
$$$$
.1870(8.54) \quad .4466(4.97)
$$$$
.0503(2.25) \quad-1.1695(13.30)
$$$$
.1953(8.92) \quad-1.5730(17.94)
$$$$
.1422(6.46) \quad-1.8912(21.48)
$$$$
-.0041(0.15) \quad .5996(5.50)
$$$$
.1491 \text { (6.74) -1.4650 (16.23) }
$$ 


\begin{tabular}{|c|c|c|c|c|}
\hline Malta & $.8118(7.34)$ & $.2218(1.97)$ & $-.3147(10.97)$ & $-.4782(4.22)$ \\
\hline Netherlands & $.6657(7.80)$ & $-.1490(1.80)$ & $-.2631(11.62)$ & .7077 (7.98) \\
\hline Poland & $.5324(6.30)$ & $.7238(8.23)$ & $.0552(2.45)$ & $-.7725(8.66)$ \\
\hline Portugal & $-.4724(5.27)$ & $.3512(3.95)$ & $.1618(7.26)$ & $-2.0441(23.35)$ \\
\hline Romania & $-.8601(9.42)$ & $1.0423(11.45)$ & $-.0617(2.73)$ & $-2.8260(32.07)$ \\
\hline Slovakia & $.2379(2.78)$ & $1.1254(13.15)$ & $.1889(8.67)$ & -.8867 (9.99) \\
\hline Slovenia & $-.0969(1.13)$ & $-.0445(0.53)$ & $.0713(3.20)$ & $-.3659(4.14)$ \\
\hline Spain & .3549 (4.07) & $.3472(3.82)$ & $.2510(11.58)$ & $-.4443(4.96)$ \\
\hline Sweden & $2.0228(23.05)$ & $.9473(11.35)$ & $.1523(7.00)$ & .8669 (9.82) \\
\hline \multicolumn{2}{|c|}{ Turkish Cyprus } & $.5669(4.89)$ & & $-1.1993(10.63)$ \\
\hline Turkey & $.1997(2.21)$ & 1934 (1.99) & $.2080(9.16)$ & $-.9630(9.93)$ \\
\hline UK & $.6303(7.79)$ & $.7395(9.23)$ & $-.1200(5.62)$ & .7489 (8.93) \\
\hline \multicolumn{2}{|c|}{ West Germany .3498 (4.16) } & $-.2990(3.53)$ & $-.0465(2.06)$ & $-.1130(1.28)$ \\
\hline /cut1 & .1006 & -1.6815 & -3.4753 & \\
\hline /cut2 & 1.8205 & -.0159 & -1.7428 & \\
\hline /cut3 & & 2.1023 & 1.2795 & \\
\hline & 28,872 & 25,418 & 30,215 & 30,580 \\
\hline \multicolumn{2}{|c|}{ Pseudo/Adjusted R ${ }^{2} .0599$} & .0286 & .0625 .1505 & \\
\hline
\end{tabular}

Source: Eurobarometer \#73.4, May 2010.

Notes: Excluded categories, Age left school<16 and ages 45-54, Belgium; EU national and married. T-statistics in parentheses.

Q1. What are your expectations for the next twelve months: will the next twelve months be better $(=3)$, worse $(=2)$ or the same $(=1)$, when it comes to the employment situation in (our country).

Q2. In a international financial and economic crisis, it is necessary to increase public deficits to create jobs Totally agree $(=4) ;$; Tend to agree $(=3)$; Tend to disagree $(=2)$; Totally disagree $(=1)$.

Q3. What do you think are the two most important issues facing (our country) at the moment - unemployment?

Q4. On the whole, are you very satisfied $(=4)$, fairly satisfied $(=3)$, not very satisfied $(=2)$ or not at all satisfied $(=1)$ with the life you lead? 
Table 9. Characteristics of individuals in the NCDS according to number of months unemployed between ages 16 and 23

Social class (1958) - I

Social class (1958) - II

Social class (1958) - III - nonmanual

Social class (1958) - III - manual

Social class (1958) - IV

Social class (1958) - V

IQ score at 11

Math score at 11

Reading score at 16

Math score at 16

Malaise score at 23

Malaise score at 50

Unemployed at age $33(\%)$

Unemployed at age 42 (\%)

Unemployed at age 50 (\%)

Very difficult financially at 50 (\%)

Happy at 50

Life satisfaction at 50

Gross weekly pay at 50

0
5
14
11
51
11
7
45.3
18.0
26.3
13.6
2.48
1.36
1.1
1.1
1.6
1.6
3.54
7.45
$£ 592$
15.1

$>0 \&<3$
5
13
10
49
15
9
45.0
17.9
26.4
13.5
2.67
1.43
0.6
1.5
1.7
3.3
3.51
7.28
$£ 578$
15.9

Number of months unemployed

No academic qualification at 50 (\%)

15.1

$\geq 3 \&<$
4
15
9
50
11
10
43.1
16.3
25.7
12.6
2.94
1.52
1.1
1.8
3.3
1.9
3.46
7.09
$£ 501$
16.4

$\geq 6 \&<12$
4
12
8
52
13
11
42.5
16.2
25.0
12.1
3.27
1.86
3.0
4.1
4.1
5.4
3.4
7.1
$£ 479$
21.4

$\begin{array}{rr}\geq 12 \&<24 & \geq 24 \\ 3 & 2 \\ 9 & 3 \\ 9 & 6 \\ 50 & 50 \\ 15 & 16 \\ 15 & 23 \\ 38.0 & 32.7 \\ 13.6 & 10.5 \\ 22.9 & 19.9 \\ 10.2 & 8.7 \\ 3.65 & 4.21 \\ 1.96 & 2.22 \\ 2.5 & 9.5 \\ 4.5 & 8.9 \\ 4.4 & 10.0 \\ 6.6 & 5.0 \\ 3.27 & 3.19 \\ 6.92 & 6.63 \\ £ 428 & £ 373 \\ 30.8 & 51.0\end{array}$

Notes; 'Very difficult financially' refers to an individual's assessment of their personal situation. Social class refers to mother's husband in the Perinatal Mortality Study in 1958. 
Table 10 . Log weekly wages in 2008/2009 at age 50

Months unemployed $\leq 23-.0138$ (10.00) -.0092 (8.10)

Male

Unemployed in 2004

Part-time dummy

Permanent job dummy

Region dummies (10)

School dummies (8)

Industry dummies (59)

Workplace size dummies (4)

Constant

5.7595

Adjusted $\mathrm{R}^{2}$

$\mathrm{N}$
(1) $.6813(35.73)$ $.3263(17.15)$

(2)

$-.0090(7.15)$

.3183 (15.63)

$-.1249(1.50)$

(3) 
Table 11. Happiness in 2008/2009 at age 50

(1)

Months unemployed $\leq 23-.0051$ (5.38) -.0048 (4.38)

Unemployed in 2004

$-.0856(1.21)$

Unemployed in 2000

$-.0659(1.03)$

Part-time employee $\quad-.0052(0.24) \quad-.0008(0.04)$

Full-time self-employed $\quad .0243(1.02) .0147(0.57)$

Part-time self-employed -.0523 (1.14) - -.0965 (1.96)

Unemployed $\quad-.1876(3.90)-.0454(0.77)$

Full-time education $\quad-.1900(1.28) \quad-.2397(1.59)$

Government scheme $\quad-.5055(1.11) \quad-.7448$ (1.17)

Temporarily sick/disabled -.0828 (0.85) -.0352 (0.34)

Permanently sick/disabled -.3755 (10.16) -.3842 (9.09)

Looking after home/family -.1183 (3.57) -.1040 (2.93)

Wholly retired $\quad-.1144(1.37) \quad-.1516(1.62)$

Other LF status $\quad .0075(0.11) \quad .0010(0.02)$

Male $\quad-.0741(4.61) \quad-.0629(4.02)$

Takes daily exercise $\quad .0482(2.83) \quad .0445(2.43)$

Smoker $\quad-.0991(5.17) \quad-.1024(4.94)$

$\begin{array}{lll}\text { Constant } & 3.2761 & 3.2970\end{array}$

$\begin{array}{lll}\text { Adjusted } \mathrm{R}^{2} & .0798 & .0727\end{array}$

N $8,4267,234 \quad 6,679$

Source: National Child Development Study - 1958 birth cohort

Notes: All equations include 10 region dummies, 5 marital status dummies and 8 schooling dummies. Excluded category full-time employees. Instruments in columns 2 and 4 are the proportion of children in the child's school whose parents are in non-manual occupations obtained from the educational interview provided by the school when the respondent was age 16. Results are reported in 8 bands - the first 7 were in $10 \%$ intervals and the last $80 \%+$ so seven dummies are included as instruments. T-statistics in parentheses.

Question. 'On balance I look back on life with a sense of happiness $(n=9,845)$. Never $=1 \%$; not often $=7 \%$; sometimes $=34 \%$ and often $58 \%$. 